\title{
SYSTEM FOR MEASURING THE WALKING SPEED OF A HUMAN SUBJECT ON A FORCE PLATE
}

\section{SISTEM DE MĂSURARE A VITEZEI DE DEPLASARE A SUBIECTULUI UMAN LA MERSUL PE O PLATFORMĂ DE FORTĂ}

\author{
Viorel GHEORGHE ${ }^{1}$, Ana Maria VASILESCU ${ }^{2 *}$, Mirela PANTAZI ${ }^{2}$ \\ ${ }^{1}$ “Politehnica” University - Faculty of Mechanical Engineering and Mechatronics, Bucharest, Romania, e-mail: viorel.gheorghe@gmail.com \\ ${ }^{2}$ INCDTP - Division: Leather and Footwear Research Institute, 93 Ion Minulescu, Bucharest, Romania, e-mail: icpi@icpi.ro
}

\section{SYSTEM FOR MEASURING THE WALKING SPEED OF A HUMAN SUBJECT ON A FORCE PLATE}

ABSTRACT. This paper presents the development of a system for measuring the walking speed on a force plate that measures ground reaction. The walking speed measurement system must meet the following criteria: minimal impact on the force plate, easy installation/dismantling, speed must be detected "without contact" and speed of subject must be detected irrespective of the subject's clothing colour, it must provide the possibility of using several types of force plate, it must allow the addition of new functions and have a competitive price. Ground reaction force was measured using the AMTI's AccuGait force plate and the NetForce component, while analysis was performed using the BioAnalysis module. To assess the three components of the ground reaction force provided by the force plate, for a subject not wearing shoes, walking at different speeds, two measurement sessions were organized: placing optical barriers of the walking speed measurement system at distances of $2.5 \mathrm{~m}$ and $0.7 \mathrm{~m}$, respectively. Upon analyzing the values obtained in this case study, we can observe an increase in values of the following components: vertical component, $\mathrm{Fz}$, medio-lateral component, Fy and anterior-posterior component, $\mathrm{Fx}$ at the speed of $2.33 \mathrm{~m} / \mathrm{s}$, compared to those obtained at $0.6 \mathrm{~m} / \mathrm{s}$. By comparing values provided by the force plate with optical barriers of the walking speed measurement system placed at distances of $2.5 \mathrm{~m}$ and $0.7 \mathrm{~m}$, respectively, very small differences can be noticed. Therefore, the position of optical barriers does not affect the measurement of ground reaction force components.

KEY WORDS: speed, walking, ground reaction force

\section{SISTEM DE MĂSURARE A VITEZEI DE DEPLASARE A SUBIECTULUI UMAN LA MERSUL PE O PLATFORMĂ DE FORTĂ}

REZUMAT. În cadrul acestei lucrări se prezintă realizarea unui sistem de măsurare a vitezei de deplasare deasupra unei platforme de măsurare a reacţiunii solului. Sistemul de măsurare a vitezei de deplasare trebuie să respecte următoarele criterii: impact minim asupra platformei, permiterea unei montări/demontări facile, detecţia vitezei să se realizeze „fără contact” şi cea a subiectului să se realizeze indiferent de culoarea îmbrăcămintei subiectului, să ofere posibilitatea folosirii la mai multe tipuri de platforme de forţă, să permită adăugarea unor noi funcţiuni şi să fie la un preţ competitiv. Măsurarea forţei de reacţiune a solului s-a realizat cu platforma AMTI's AccuGait, folosind componenta NetForce, iar analiza acesteia s-a realizat cu modulul BioAnalysis. Pentru evaluarea celor trei componente ale forţei de reacţiune a solului furnizate de platforma de forţă, în cazul unui subiect ce nu poartă încălţăminte, mergând cu viteze diferite, au fost organizate două sesiuni de măsurare: amplasarea barierelor optice ale sistemului de măsurare a vitezei de mers la distanţa de $2,5 \mathrm{~m}$, respectiv $0,7 \mathrm{~m}$. Analizând valorile obţinute în acest studiu de caz, se poate observa o creştere a valorilor componentelor: verticale $\mathrm{Fz}$, medio-laterale $\mathrm{Fy}$ şi a celei antero-posterioare $\mathrm{Fx}$ la viteza de $2,33 \mathrm{~m} / \mathrm{s}$ faţă de cele obţinute la $0,6 \mathrm{~m} / \mathrm{s}$. Prin compararea valorilor furnizate de platforma de forţă având barierele optice ale sistemului de măsurare a vitezei de mers la distanţele de $2,5 \mathrm{~m}$ şi $0,7 \mathrm{~m}$, se observă diferenţe foarte mici. Deci, amplasarea barierelor optice ale sistemului nu influenţează măsurarea valorilor componentelor forţei de reacţiune a solului.

CUVINTE CHEIE: viteză, mers, forţa de reacţiune a solului

\section{SYSTÈME DE MESURER LA VITESSE DE MARCHE D'UN SUJET SUR UNE PLATEFORME DE FORCE}

RÉSUMÉ. Dans cet article on présente le développement d'un système de mesurer la vitesse de marche sur une plateforme qui mesure la réaction du sol. Le système de mesurer la vitesse de marche doit répondre aux critères suivants : un impact minimal sur la plateforme, permettre un montage/démontage facile, la détection de la vitesse doit être "sans contact" et cela du sujet doit être détectée sans tenir compte de la couleur de l'habillement du sujet, fournir la possibilité d'utiliser plusieurs types de plateforme de force, permettre d'ajouter de nouvelles fonctions et d'avoir un prix compétitif. La force de réaction du sol a été mesurée avec la plateforme AccuGait de AMTI en utilisant le composant NetForce et on a effectué l'analyse en utilisant le module BioAnalysis. Pour évaluer les trois composantes de la force de réaction du sol fournis par la plateforme de force, pour un sujet marchant sans chaussures à des vitesses différentes, on a organisé deux sessions de mesure : en installant les barrières optiques du système de mesurer la vitesse de marche aux distances de 2,5 $\mathrm{m}$ et 0,7 m. L'analyse des valeurs obtenues dans cette étude de cas a montré une augmentation dans les composants suivants: le composant vertical Fz, le composant médio-latéral Fy et le composant antéro-postérieur Fx à une vitesse de 2,33 m/s, par rapport à celles obtenues à $0,6 \mathrm{~m} / \mathrm{s}$. En comparant les valeurs fournis par les barrières optiques du système de mesurer la vitesse de marche aux distances de $2,5 \mathrm{~m}$ et $0,7 \mathrm{~m}$, on peut observer de petites différences. Donc, la position des barrières optiques du système n'affecte pas la mesure des valeurs des composantes de la force de réaction du sol.

MOTS-CLÉS: vitesse, marche, force de réaction du sol

* Correspondence to: Ana Maria VASILESCU, INCDTP - Division: Leather and Footwear Research Institute, 93 Ion Minulescu, Bucharest, Romania, e-mail: icpi@icpi.ro 


\section{INTRODUCTION}

In order to scientifically design footwear for people with normal gait, who do not have severe pathologies, and thus contribute to optimization of methods of preventing medical complications manifested in the foot, it is necessary to use gait recording techniques and equipment. Previous studies have shown that measurement of plantar pressure [1] and ground reaction underlie the discovery of foot conditions, and walking speed is a crucial indicator in gait analysis. Measuring the walking speed in a clinical setting is carried out using various methods [2-3].

To measure the speed at which a subject is walking on a ground reaction measurement platform, it was necessary to create a system specifically for this purpose. The speed measurement system must meet a number of criteria:

- minimal impact on the force plate;

- easy installation/dismantling;

- speed must be detected "without contact";

- speed of subject must be detected irrespective of the subject's clothing colour;

- it must provide the possibility of using several types of force plate;

- it must allow the addition of new functions;

- competitive price.

\section{METHOD}

The starting point for building the speed measurement system when walking on the force plate that meets the above criteria was the Arduino Duemilanove prototyping platform, Figure 1 [4].

\section{INTRODUCERE}

În vederea proiectării pe baze ştiinţifice a încălţămintei destinate persoanelor cu mers normal, fără patologii severe, contribuind astfel la optimizarea metodelor de prevenţie a complicaţiilor medicale manifestate la nivelul piciorului, se impune utilizarea unor tehnici şi echipamente de înregistrare a mersului. Studiile anterioare au arătat că măsurarea presiunilor plantare [1], a reacţiunii solului, stau la baza descoperirii problemelor picioarelor, iar viteza de deplasare este un indicator fundamental în analiza mersului. Măsurarea vitezei de deplasare într-un cadru clinic se realizează folosind diferite metode [2-3].

Pentru măsurarea vitezei cu care un subiect se deplasează deasupra unei platforme de măsurare a reacţiunii solului, a fost necesară crearea unui sistem în acest scop. Sistemul de măsurare a vitezei trebuie să respecte o serie de criterii:

- impact minim asupra platformei de forţă;

- permiterea unei montări/demontări facile;

- detecţia vitezei să se realizeze „fără contact”;

- detecţia subiectului să se realizeze indiferent de culoarea îmbrăcămintei;

- să ofere posibilitatea folosirii la mai multe tipuri de platforme de forţă;

- să permită adăugarea unor noi funcţiuni;

- preţcompetitiv.

\section{METODĂ}

Pentru construirea sistemului de măsurare a vitezei de deplasare pe platforma de forţă care să îndeplinească criteriile amintite mai sus, s-a pornit de la platforma de prototipare Arduino Duemilanove, Figura 1 [4].

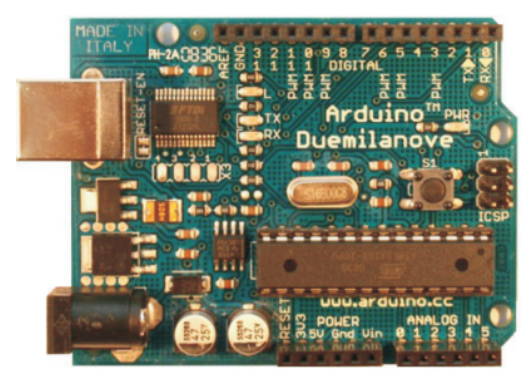

Figure 1. Ardunino Duemilanove prototyping platform [4]

Figura 1. Platforma prototipare Ardunino Duemilanove [4] 
This allowes us to reduce design and implementation time of the adopted solution. To easily and safely connect most component elements of the system, a custom-made "Arduino" shield was created.

"No contact" detection of subject under the above conditions is carried out by two WE-M4D optical sensors, each containing a modulated light transmitter and an optical receiver, respectively. Transmitted light is reflected in a reflector and captured by the receiver. If the luminous flux is interrupted by an object interposed between the transducer and the reflector, the transducer sends a logical signal "1" for as long as the luminous flux is disrupted, Figure 2 [5].
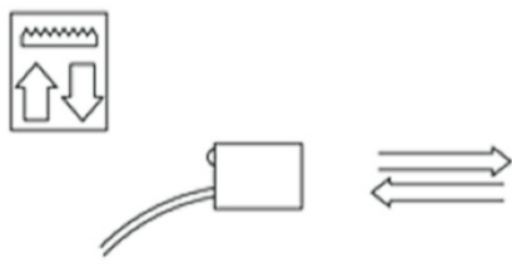

Figure 2. WE-M4D retro-reflective optical sensor [5]

Figura 2. Senzor optic retro-reflectiv WE-M4D [5]
Acest lucru a permis reducerea timpului de proiectare şi implementare a soluţiei adoptate. Pentru conectarea uşoară şi sigură a majorităţii elementelor ce intră în componenţa sistemului s-a realizat un scut "Arduino" personalizat.

Detecţia "fără contact" a subiectului în condiţiile menţionate anterior este realizată de către doi senzori optici WE-M4D, care conţin fiecare câte un emiţător de lumină modulată, respectiv câte un receptor optic. Lumina ce este emisă se reflectă într-un catadioptru şi este captată de receptor. În cazul în care fluxul luminos este întrerupt de către un obiect interpus între traductor şi catadioptru, traductorul va trimite un semnal logic "1" atâta timp cât fluxul luminos este perturbat, Figura 2 [5].

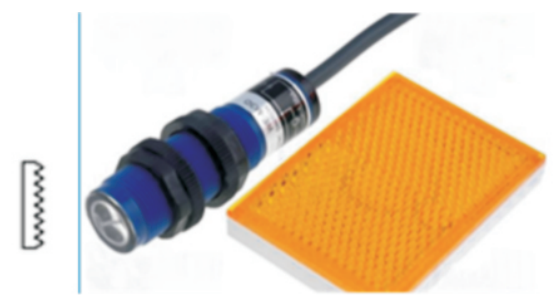

\section{Block Diagram of Speed Measuring System}

The speed measurement system is schematically presented in Figure 3. It is made up of a central unit 1 and two optical barriers: the first one consists of transducer $T_{1} 2$, working in tandem with receptor 3 , and the second one consists of transducer $\mathrm{T}_{2} 4$ and receptor 5. When subject 7 steps onto the force plate 6 and activates the first optical barrier, a timer starts and stops when the second optical barrier is activated. Knowing the distance " $d$ " between the two barriers and the time it took to cover it, the average speed of the subject is determined.

\section{Schema bloc a sistemului de măsurare a vitezei}

Sistemul de măsurare a vitezei este prezentat schematic în Figura 3. Acesta este alcătuit dintr-o unitate centrală 1 şi două bariere optice: prima este formată de traductorul $T_{1} 2$, ce lucrează în tandem cu catadioptrul 3, respectiv a doua, ce este formată din traductorul $\mathrm{T}_{2} 4$ şi catadioptrul 5. În momentul în care subiectul 7 păşeşte pe platforma de forţă 6 şi activează prima barieră optică, se porneşte un cronometru ce se va opri în momentul activării celei de-a doua bariere optice. Cunoscându-se distanţa "d" dintre cele două bariere şi timpul în care aceasta a fost străbătută, se determină viteza medie a subiectului. 


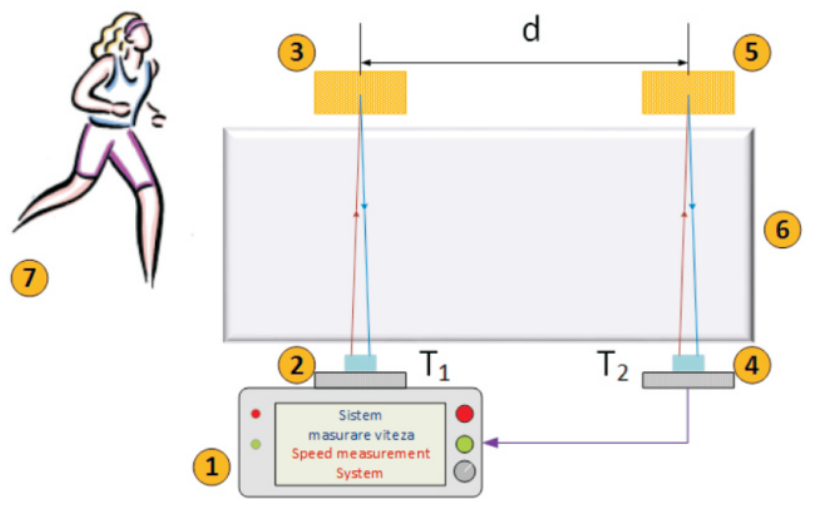

Figure 3. Speed measuring system

Figura 3. Sistem de măsurare viteză

\section{The Central Unit of Speed Measuring System}

It consists of the following elements, Figure 4:

- 1-Arduino Duemilanove chip:

- ATmega368 microcontroller;

- 14 digital input/output pins;

- 6 analog input pins;

o USB programming;

o voltage 7-12V;

- 2, 3 - subassembly consisting of the retroreflective optical transducer with WE-M4D reflector and 4N35 optocoupler that performs galvanic separation between the transducer and Arduino chip and correlates the different voltage levels on which these devices operate. Such a subassembly makes up an optical barrier;

- 4 - liquid crystal display and lighting of $16 \times 2$ alphanumeric characters;

- 5,6-normal red and green open button;

- 7-incremental rotary encoder;

- 8,9-red and green LED indicators;

- 10 - piezo mini speaker, used for various acoustic warnings.

\section{Unitatea centrală a sistemului de măsurare a vitezei}

Aceasta este compusă din următoarele elemente, Figura 4:

- 1-placa de dezvoltare Arduino Duemilanove:

o microcontroler ATmega368;

- 14 pini de intrare/iesire digitali;

- 6 pini intrare analogici;

o programare via USB;

o tensiune alimentare 7-12V;

- 2, 3 - subansamblu format din traductorul optic retroreflectiv cu catadioptru WE-M4D şi optocuplorul 4N35 ce realizează separarea galvanică dintre traductor şi placa Arduino şi corelează nivelele de tensiune diferite cu care operează aceste dispozitive. Un asemenea subansamblu alcătuieşte o barieră optică;

- 4-ecran cu cristale lichide şi iluminare de $16 \times 2$ caractere alfanumerice;

- 5, 6- buton normal deschis de culoare roşie, respectiv verde;

- 7-traductor incremental mecanic de rotaţie;

- 8, 9 - LED-uri indicatoare de culoare roşie, respectiv verde;

- 10 - minidifuzor piezo, folosit pentru diverse atenţionări acustice. 


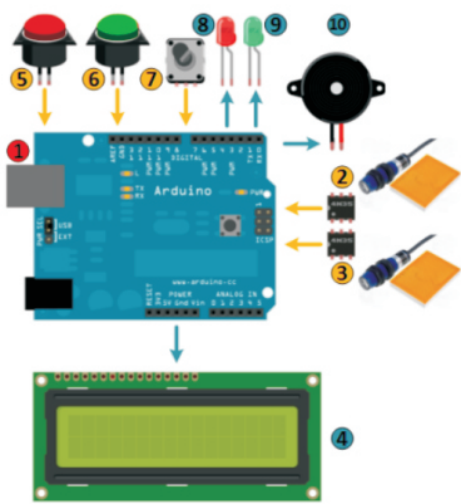

Figure 4. Central unit of the measuring system. Fritzing [6] was also used for representation Figura 4. Unitatea centrală a sistemului de măsurare. Pentru reprezentare s-a utilizat şi Fritzing [6]

\section{Working Algorithm of the Speed Measuring System}

When the system is powered, it runs a series of checks/initializations.

\section{Algoritmul de lucru al sistemului de măsurare a vitezei}

La alimentarea cu tensiune a sistemului, acesta execută o serie de verificări/iniţializări.

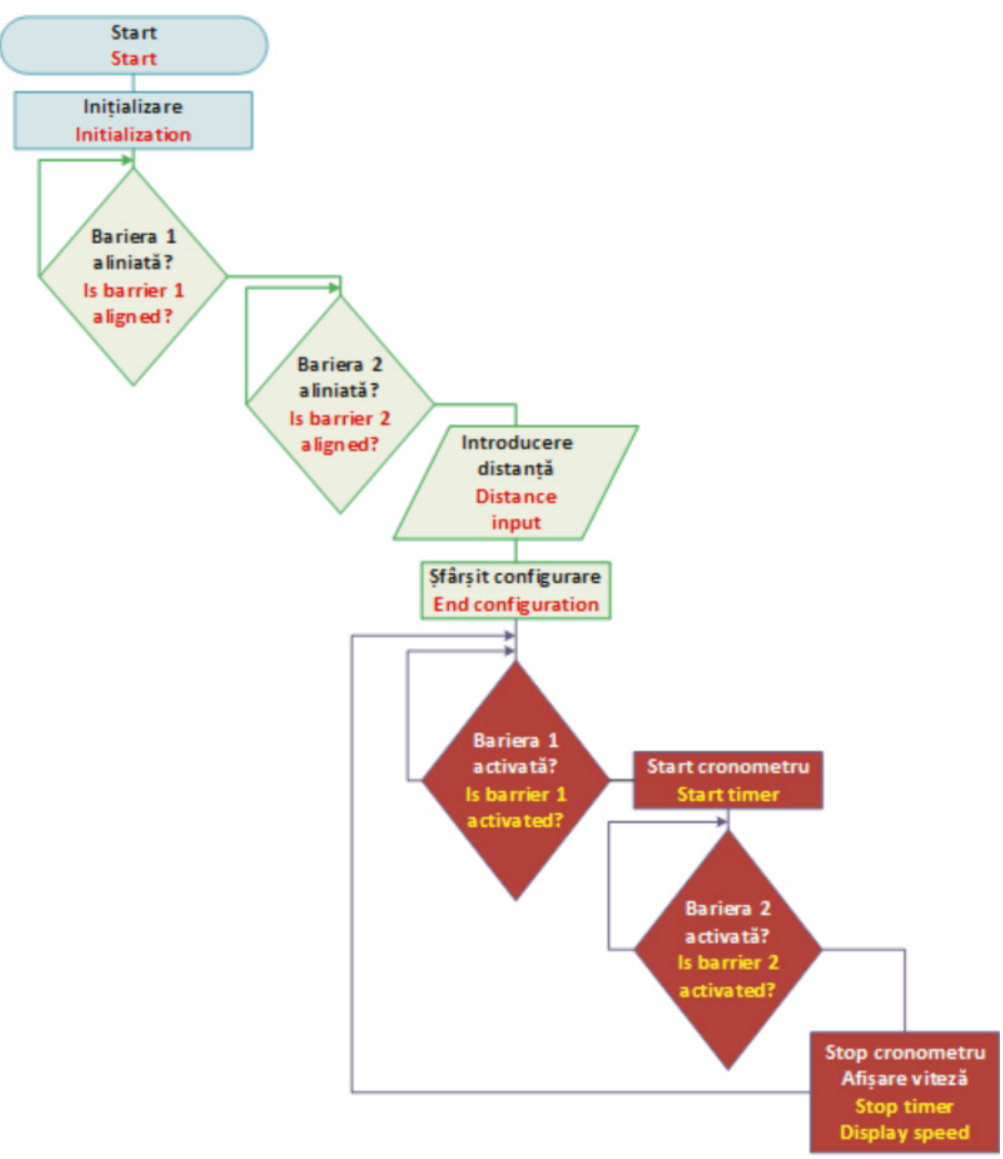

Figure 5. Working algorithm of the measuring system

Figura 5. Algoritmul de lucru al sistemului de măsurare 
After this short period, the system configuration routine starts. The first optical barrier is aligned so that transducer $T_{1}$ correctly receives the signal reflected by its own reflector. When the alignment is correct, the red button on the central unit is pressed to confirm. The process is repeated for the second barrier.

Then the distance between the two barriers is entered using the incremental rotary encoder. This solution was chosen in order to be able to more easily enter the distance. The configuration is confirmed and the system is ready to go.

When the subject reaches the first optical barrier, the timer starts and stops when the subject reaches the second barrier. The activation of each barrier is accompanied by an acoustic signal.

The average speed of the subject is displayed on the LCD screen located to the front of the central unit.

\section{RESULTS AND DISCUSSIONS}

\section{Measuring Ground Reaction Force Based on Walking Speed}

Ground reaction force was measured depending on the walking speed on AMTI's AccuGait force plate, using NetForce component, and its analysis was performed using the BioAnalysis module. For evaluation, two measurement sessions were organized:

- placing optical barriers of the walking speed measurement system at a distance of $2.5 \mathrm{~m}$, Figure 6a;

- placing optical barriers of the walking speed measurement system at a distance of $0.7 \mathrm{~m}$, Figure $6 \mathrm{~b}$.

A healthy female subject volunteered to participate in the study, aged 54 and weighing $70 \mathrm{~kg}$, who walked on the track where the force plate was set up. Only those instances where the right foot landed entirely on the force plate were validated. The subject walked barefoot on the track.
După această scurtă perioadă se porneşte rutina de configurare a sistemului. Se aliniază prima barieră optică astfel încât traductorul $T_{1}$ să primească corect semnalul reflectat de catadioptrul propriu. Când alinierea este corectă se confirmă prin apăsarea butonului roşu de pe unitatea centrală. Se repetă procedeul şi pentru cea de-a doua barieră.

Apoi se introduce distanţa dintre cele două bariere prin intermediul traductorului incremental mecanic de rotaţie. S-a ales această soluţie pentru a putea introduce distanţa într-un mod mai facil. Se confirmă efectuarea configurării şi sistemul este gata de acţiune.

În momentul în care subiectul ajunge în dreptul primei bariere optice se porneşte cronometrarea ce se opreşte în momentul în care subiectul se află, de data aceasta, în zona celei de-a doua bariere. Activarea fiecărei bariere este însoţită de un semnal acustic.

Afişarea vitezei medie a subiectului este afişată pe ecranul LCD amplasat în zona frontală a unităţii centrale.

\section{REZULTATE ŞI DISCUTII}

\section{Măsurarea forţei de reacţiune a solului în funcţie de viteza de deplasare}

Măsurarea forţei de reaç̧iune a solului în funcţie de viteza de deplasare s-a realizat cu platforma de forţă AMTI's AccuGait, folosind componenta NetForce, iar analiza acesteia s-a realizat cu modulul BioAnalysis. Pentru evaluare, au fost organizate două sesiuni de măsurare:

- amplasarea barierelor optice ale sistemului de măsurare a vitezei de mers la distanţa de 2,5 m, Figura 6a;

- amplasarea barierelor optice ale sistemului de măsurare a vitezei de mers la distanţa de 0,7 m, Figura 6 b.

La studiu a participat un voluntar de sex feminin sanatos cu vârsta de 54 ani, cu greutatea corporala de $70 \mathrm{~kg}$, ce a mers pe pista în care a fost introdusa platforma de forta. Au fost validate numai acele treceri în care piciorul drept a aterizat în întregime pe suprafata platformei de forta. Subiectul a mers pe pista fara încaltaminte. 


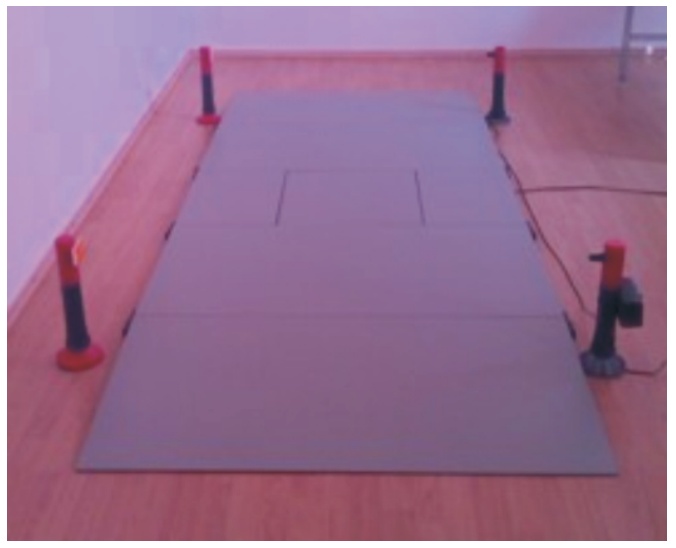

a.

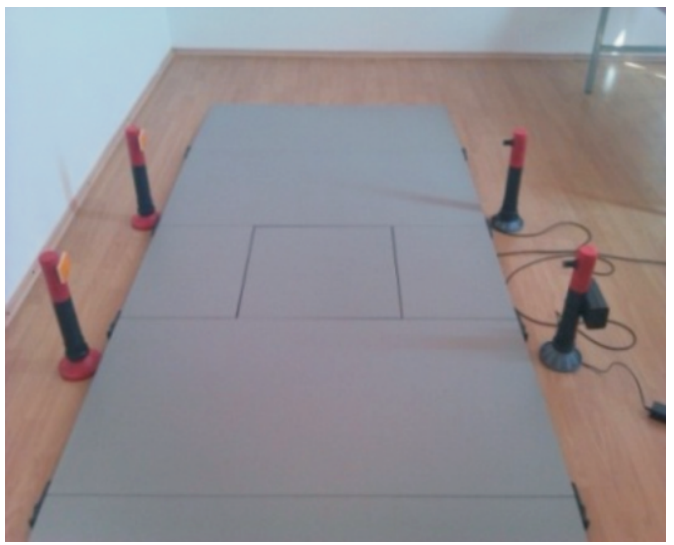

b.

Figure 6. Position of optical barriers of the walking speed measuring system at distance: $a=2.5 \mathrm{~m}, \mathrm{~b}=0.7 \mathrm{~m}$ Figura 6. Amplasarea barierelor optice ale sistemului de măsurare a vitezei de mers la distanţa: $a=2,5 \mathrm{~m}, \mathrm{~b}=0,7 \mathrm{~m}$

The reference system of the force plate is presented in Figure 7.

Sistemul de referinţă al platformei de forţă este prezentat în Figura 7.

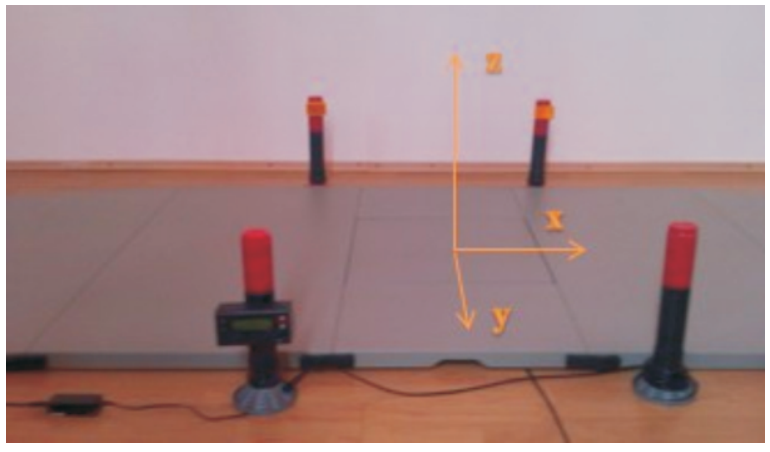

Figure 7. Reference system for AMTI's AccuGait force plate Figura 7. Sistem de referinţă al platformei de forţă AMTI's AccuGait

Measuring Ground Reaction Force Based on Walking Speed, with the Distance of $2.5 \mathrm{~m}$ between Optical Barriers

Tables 1 and 2 present maximum values of the three components ( $F z, F y, F x)$ of ground reaction force obtained at walking speeds ranging between $0.6 \div 2.33 \mathrm{~m} / \mathrm{s}$, with optical barriers placed at a distance of $2.5 \mathrm{~m}$.
Măsurarea forţei de reacţiune a solului în funcţie de viteza de mers, cu distanţa de 2,5 m între barierele optice

În Tabelele 1 şi 2 sunt prezentate valorile maxime ale celor trei componente ( $F z, F y, F x)$ ale forţei de reacţiune a solului obţinute la vitezele de mers cuprinse între $0,6 \div 2,33 \mathrm{~m} / \mathrm{s}$, cu barierele optice amplasate la distanţa de $2,5 \mathrm{~m}$. 
Table 1: Maximum values of the three components ( $F x, F y, F z)$ of ground reaction force obtained at the walking speed of subject ranging between $0.6 \div 0.8 \mathrm{~m} / \mathrm{s}$

Tabelul 1: Valorile maxime ale celor trei componente ( $F x, F y, F z)$ ale forţei de reacţiune a solului obţinute la viteza de mers a subiectului cuprinsă între $0,6 \div 0,8 \mathrm{~m} / \mathrm{s}$

\begin{tabular}{|c|c|c|c|c|c|c|}
\hline $\begin{array}{c}\text { Speed }[\mathrm{m} / \mathrm{s}] \\
\text { Viteza }[\mathrm{m} / \mathrm{s}]\end{array}$ & 0.6 & 0.65 & 0.66 & 0.75 & 0.78 & 0.8 \\
\hline \hline Fz Max [N] & 680.536 & 680.672 & 681.2 & 701.583 & 733.964 & 694.567 \\
\hline Fy Max [N] & 10.027 & 13.413 & 9.116 & 12.111 & 14.195 & 12.111 \\
\hline Fx Max [N] & 75.229 & 61.116 & 66.515 & 72.038 & 78.051 & 73.511 \\
\hline
\end{tabular}

Table 2: Maximum values of the three components ( $F x, F y, F z)$ of ground reaction force obtained at the walking speed of subject ranging between $1 \div 2.33 \mathrm{~m} / \mathrm{s}$

Tabelul 2: Valorile maxime ale celor trei componente ( $F x, F y, F z)$ ale forţei de reaç̧iune a solului obţinute la viteza de mers a subiectului cuprinsă între $1 \div 2,33 \mathrm{~m} / \mathrm{s}$

\begin{tabular}{c|c|c|c|c|c|c|}
\hline $\begin{array}{c}\text { Speed }[\mathrm{m} / \mathrm{s}] \\
\text { Viteza }[\mathrm{m} / \mathrm{s}]\end{array}$ & 1 & 1.03 & 1.15 & 1.32 & 1.91 & 2.33 \\
\hline \hline Fz Max $[\mathrm{N}]$ & 701.044 & 728.567 & 708.059 & 732.885 & 996.248 & 1109.581 \\
\hline Fy Max $[\mathrm{N}]$ & 22.789 & 20.315 & 32.556 & 29.04 & 30.342 & 40.5 \\
\hline Fx Max $[\mathrm{N}]$ & 64.92 & 71.424 & 81.487 & 67.006 & 66.147 & 67.865 \\
\hline
\end{tabular}

Evolution of the three components ( $F x, F y, F z)$ of ground reaction force obtained at walking speeds ranging between $0.6 \div 2.33 \mathrm{~m} / \mathrm{s}$ is illustrated in Figure 8 .

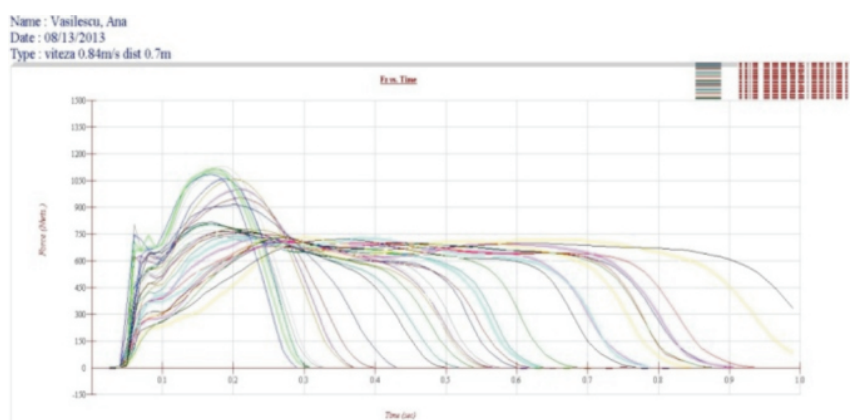

a.

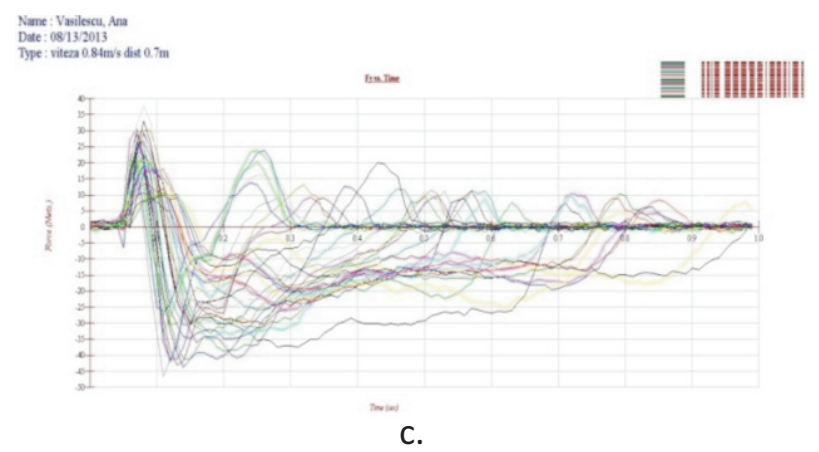

Figure 8. Ground reaction force components, varying with time, at different walking speeds $\mathrm{a}$ - vertical Fz, b-antero-posterior Fx, c-medio-lateral Fy

Figura 8. Componentele forţei de reacţiune a solului, în funcţie de timp, la diferite viteze de mers $\mathrm{a}$ - verticală Fz, b - antero-posterioară Fx, c - medio-laterală Fy 
Measuring Ground Reaction Force Based on Walking Speed, with the Distance of $0.7 \mathrm{~m}$ between Optical Barriers

Tables 3-5 present maximum values of the three components $(F z, F y, F x)$ of ground reaction force obtained at walking speeds ranging between $0.46 \div 2.32 \mathrm{~m} / \mathrm{s}$, with optical barriers placed at a distance of $0.7 \mathrm{~m}$.

\section{Măsurarea forţei de reacţiune a solului în funcţie de viteza de mers, cu distanţa de 0,7 m între barierele optice}

În Tabelele 3-5 sunt prezentate valorile maxime ale celor trei componente ( $F z, F y, F x)$ ale forţei de reacţiune a solului obţinute la vitezele de mers cuprinse între $0,46 \div 2,32 \mathrm{~m} / \mathrm{s}$, cu barierele optice amplasate la distanţa de $0,7 \mathrm{~m}$.

Table 3: Maximum values of the three components ( $F x, F y, F z)$ of ground reaction force obtained at the walking speed of subject ranging between $0.46 \div 0.71 \mathrm{~m} / \mathrm{s}$

Tabelul 3: Valorile maxime ale celor trei componente (Fx, Fy, Fz) ale forţei de reacţiune a solului obţinute la viteza de mers a subiectului cuprinsă între $0,46 \div 0,71 \mathrm{~m} / \mathrm{s}$

\begin{tabular}{|c|c|c|c|c|c|c|c|c|c|}
\hline $\begin{array}{c}\text { Speed }[\mathrm{m} / \mathrm{s}] \\
\text { Viteza }[\mathrm{m} / \mathrm{s}]\end{array}$ & 0.46 & 0.57 & 0.58 & 0.59 & 0.60 & 0.64 & 0.68 & 0.69 & 0.71 \\
\hline \hline Fz Max $[\mathrm{N}]$ & 0 & 707.52 & 0 & 724.789 & 712.377 & 732.345 & 732.885 & 725.869 & 723.17 \\
\hline Fy Max $[\mathrm{N}]$ & 9.897 & 17.32 & 10.678 & 19.273 & 18.362 & 20.966 & 18.883 & 19.273 & 10.548 \\
\hline Fx Max $[\mathrm{N}]$ & 69.338 & 85.046 & 69.583 & 74.738 & 68.847 & 77.56 & 83.083 & 75.106 & 86.887 \\
\hline
\end{tabular}

Table 4: Maximum values of the three components ( $F x, F y, F z)$ of ground reaction force obtained at the walking speed of subject ranging between $0.76 \div 1.27 \mathrm{~m} / \mathrm{s}$

Tabelul 4: Valorile maxime ale celor trei componente ( $F x, F y, F z)$ ale forţei de reacţiune a solului obţinute la viteza de mers a subiectului cuprinsă între $0,76 \div 1,27 \mathrm{~m} / \mathrm{s}$

\begin{tabular}{|c|c|c|c|c|c|c|c|c|c|}
\hline $\begin{array}{c}\text { Speed }[\mathrm{m} / \mathrm{s}] \\
\text { Viteza }[\mathrm{m} / \mathrm{s}]\end{array}$ & 0.76 & 0.8 & 0.9 & 0.98 & 1.02 & 1.04 & 1.07 & 1.26 & 1.27 \\
\hline \hline Fz Max $[\mathrm{N}]$ & 697.805 & 767.424 & 757.71 & 745.297 & 762.567 & 805.741 & 805.741 & 740.98 & 728.567 \\
\hline Fy Max $[\mathrm{N}]$ & 14.585 & 22.659 & 26.826 & 29.822 & 29.17 & 25.524 & 29.822 & 23.571 & 20.185 \\
\hline Fx Max $[\mathrm{N}]$ & 85.66 & 82.101 & 71.67 & 66.884 & 60.257 & 59.397 & 57.802 & 85.292 & 72.283 \\
\hline
\end{tabular}

Table 5: Maximum values of the three components ( $F x, F y, F z)$ of ground reaction force obtained at the walking speed of subject ranging between $1.33 \div 2.32 \mathrm{~m} / \mathrm{s}$

Tabelul 5: Valorile maxime ale celor trei componente ( $F x, F y, F z)$ ale forţei de reacţiune a solului obţinute la viteza de mers a subiectului cuprinsă între $1,33 \div 2,32 \mathrm{~m} / \mathrm{s}$

\begin{tabular}{|c|c|c|c|c|c|c|c|c|c|}
\hline $\begin{array}{c}\text { Speed }[\mathrm{m} / \mathrm{s}] \\
\text { Viteza }[\mathrm{m} / \mathrm{s}]\end{array}$ & 1.33 & 1.38 & 1.42 & 1.53 & 1.57 & 1.59 & 1.67 & 1.68 & 2.32 \\
\hline \hline Fz Max $[\mathrm{N}]$ & 955.772 & 1002.185 & 1057.772 & 1130.089 & 1096.629 & 1111.74 & 1116.597 & 1062.089 & 1087.994 \\
\hline Fy Max $[\mathrm{N}]$ & 28.91 & 30.603 & 20.966 & 18.492 & 23.831 & 18.101 & 20.445 & 26.566 & 19.143 \\
\hline Fx Max $[\mathrm{N}]$ & 61.729 & 76.579 & 79.769 & 72.774 & 75.842 & 81.978 & 92.778 & 103.7 & 92.532 \\
\hline
\end{tabular}

Evolution of the three components (Fx, Fy, Fz) of ground reaction force obtained at walking speeds ranging between $0.6 \div 2.33 \mathrm{~m} / \mathrm{s}$ is illustrated in Figure 9 .
Evoluţiile celor trei componente (Fx, Fy, Fz) ale forţei de reacţiune a solului obţinute la viteza de mers a subiectului cuprinsă între $0,6 \div 2,33 \mathrm{~m} / \mathrm{s}$ sunt prezentate în Figura 9. 


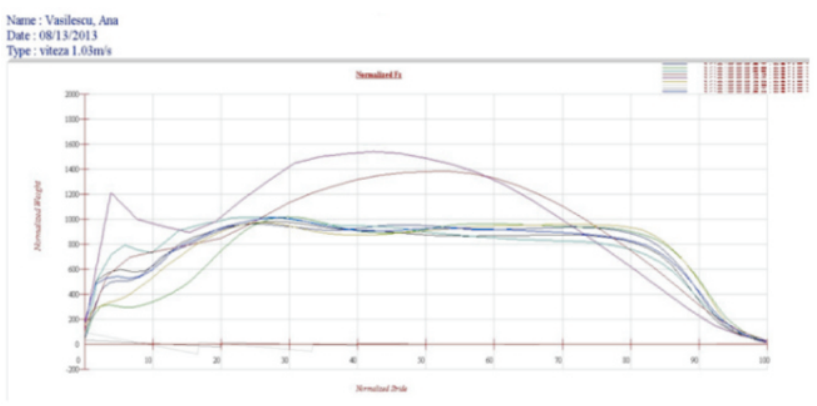

a.

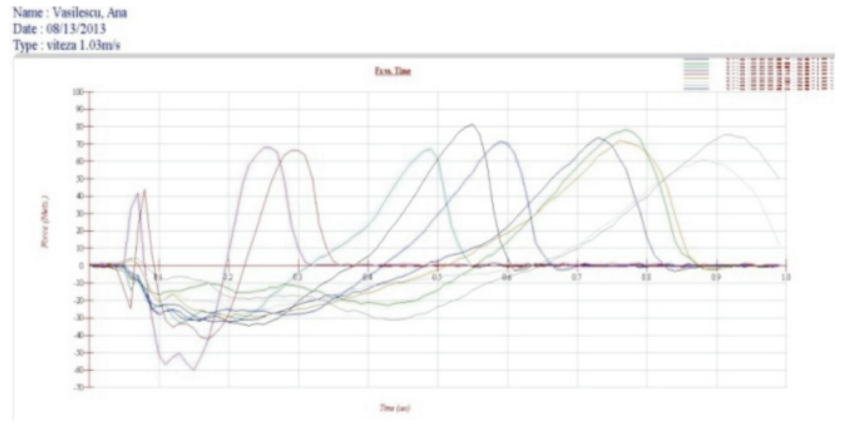

b.

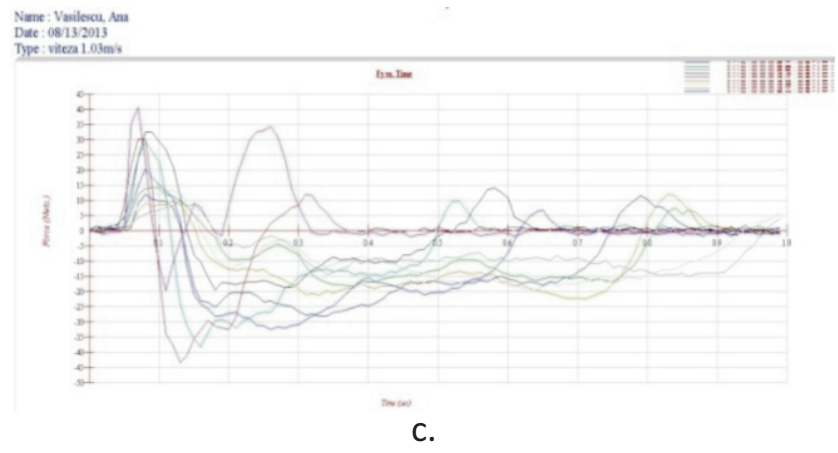

Figure 9. Ground reaction force components, varying with time, at different walking speeds

$\mathrm{a}$ - vertical Fz, b - antero-posterior Fx, c - medio-lateral Fy

Figura 9. Componentele forţei de reaç̧iune a solului, în funcţie de timp, la diferite viteze de mers $a$ - verticală Fz, b - antero-posterioară Fx, c - medio-laterală Fy

\section{Data Analysis}

Results of ground reaction force measurement enable an objective analysis of the influence of walking speed on gait biomechanics. Thus, the following are noticed: an increase of vertical component $\mathrm{Fz}$ by $58 \%$ at a speed of $2.33 \mathrm{~m} / \mathrm{s}$ compared to the one obtained at $0.6 \mathrm{~m} / \mathrm{s}$, an increase of medio-lateral component Fy by $119 \%$ at a speed of $2.33 \mathrm{~m} / \mathrm{s}$ compared to the one obtained at $0.6 \mathrm{~m} / \mathrm{s}$, and an increase of anteroposterior component Fx by $69 \%$ at a speed of $2.33 \mathrm{~m} / \mathrm{s}$ compared to the one obtained at $0.6 \mathrm{~m} / \mathrm{s}$.

The differences between values of ground reaction force components provided by the force plate with optical barriers of the walking speed measurement system placed at distances of $2.5 \mathrm{~m}$ and $0.7 \mathrm{~m}$, respectively, are very low. It can be concluded that the position of the optical barriers of the system does not influence the measurement of ground reaction force components values.

Simultaneous evolutions of the three ground reaction force components at walking speeds of 0.6 $\mathrm{m} / \mathrm{s}$ and $2.33 \mathrm{~m} / \mathrm{s}$ are illustrated in Figure 10 .

\section{Analiza datelor}

Rezultatele măsurătorilor forţei de reacţiune a solului permit o analiză obiectivă a influenţei vitezei de mers asupra biomecanicii mersului. Astfel, se observă: o creştere a componentei verticale $\mathrm{Fz}$ cu un procent de $58 \%$ la viteza de $2,33 \mathrm{~m} / \mathrm{s}$ faţă de cea obţinută la 0,6 $\mathrm{m} / \mathrm{s}$, o creştere a componentei medio-laterale Fy cu un procent de $119 \%$ la viteza de $2,33 \mathrm{~m} / \mathrm{s}$ faţă de cea obţinută la $0,6 \mathrm{~m} / \mathrm{s}$ şi o creştere a componentei anteroposterioare $\mathrm{Fx}$ cu un procent de $69 \%$ la viteza de 2,33 $\mathrm{m} / \mathrm{s}$ faţă de cea obţinută la $0,6 \mathrm{~m} / \mathrm{s}$.

Diferenţele între valorile componentelor forţei de reacţiune a solului furnizate de platforma de forţă având barierele optice ale sistemului de măsurare a vitezei de mers la distanţa de 2,5 $\mathrm{m}$ şi la distanţa de 0,7 $\mathrm{m}$ sunt foarte mici. Se poate concluziona că amplasarea barierelor optice ale sistemului nu influenţează măsurarea valorilor componentelor forţei de reacţiune a solului.

Evoluţiile simultane ale celor trei componente ale forţei de reacţiune a solului la vitezele de mers de 0,6 m/s şi 2,33 m/s sunt prezentate în Figura 10. 


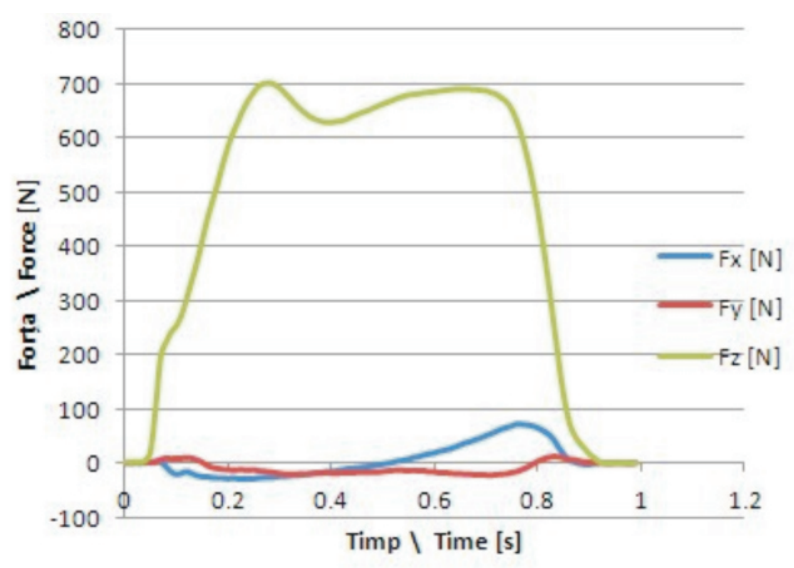

a.

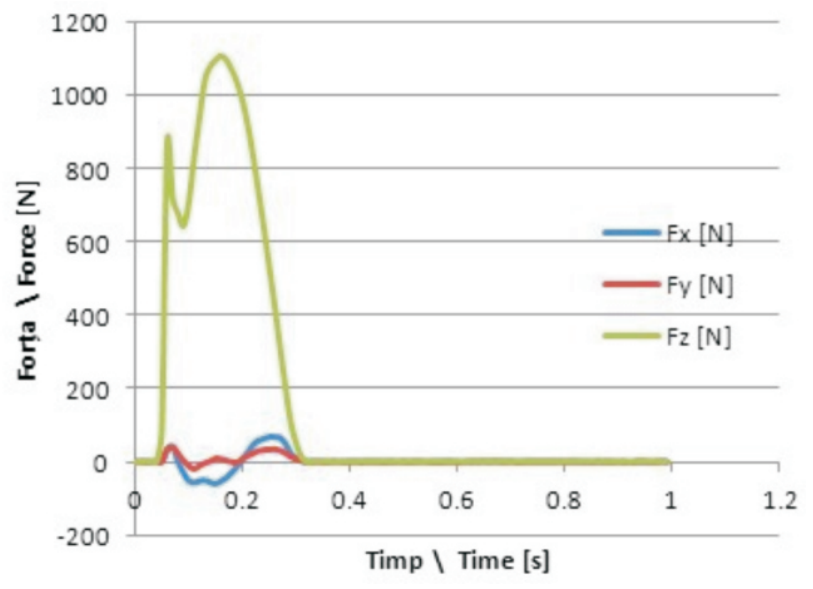

b.

Figure 10. Simultaneous evolution of the three components of the ground reaction force,

Fz, Fy, Fx, at speeds: a. $-0.6 \mathrm{~m} / \mathrm{s}$, b. $-2.33 \mathrm{~m} / \mathrm{s}$

Figura 10. Evoluţia simultană a celor trei componente ale forţei de reacţiune a solului,

Fz, Fy, Fx la viteza de: a. - 0,6 m/s, b. - 2,33 m/s

\section{CONCLUSIONS}

- The paper presents the development of a walking speed measurement system on a ground reaction measurement force plate, in order to objectively analyse gait biomechanics.

- Structural particularities of the speed measurement system meet the required criteria, allowing a correct and easy measurement of walking speed and having a competitive price.

- Measurement results demonstrated that there are no significant differences between values of ground reaction force components depending on the placement of optical barriers of the walking speed measurement system.

- Graphs and values of ground reaction force components demonstrate the influence of walking speed on the ground reaction force.

\section{CONCLUZII}

- Lucrarea prezintă realizarea unui sistem de măsurare a vitezei de mers deasupra unei platforme de măsurare a reacţiunii solului, în vederea unei analize obiective a biomecanicii mersului.

- Particularităţile construcţiei sistemului de măsurare a vitezei respectă criteriile impuse, permiţând o măsurare corectă şi facilă a vitezei de deplasare, având un preţ competitiv.

- Rezultatele măsurătorilor au demonstrat că nu există diferenţe semnificative între valorile componentelor forţei de reacţiune a solului în funcţie de poziţionarea barierelor optice ale sistemului de măsurare a vitezei de deplasare.

- Graficele şi valorile componentelor forţei de reacţiune a solului demonstrează influenţa vitezei de mers asupra forţei de reacţiune a solului.

\section{REFERENCES}

1. Mihai, A., Hortal, G., Costea, M., Plantar footprint analysis-case study (part 1), Revista de Pielarie Incaltaminte, 2013, 13, 3, 201-210, ISSN 1583-4433.

2. Li, Q., Young, M., Naing, V., Donelan, J.M., Walking speed estimation using a shank-mounted inertial measurement unit, J Biomech, 2010, 28, 43(8), 1640-1643. 
3. Schimpl, M., Ledere, C., Daumer, M., Development and Validation of a New Method to Measure Walking Speed in Free-Living Environments Using the Actibelt Platform, PloS One, 6(8), 2011, PMC3151278, DOI: 10.1371/journal.pone.0023080.

4. http://arduino.cc

5. http://www.highlyusa.com

6. http://fritzing.org/

7. AMTI-AccuGait force plate and BioAnalysis documentation.

8. Chan, C.W., Rudins, A., Foot Biomechanics During Walking and Running, Mayo Clin Proc, 1994, 69, 5, 448-461.

9. Vasilescu, A.M., Berijan, G., Jidiuc, B., Influence of the foot biomechanics on the footwear design, Revista de Pielarie Incaltaminte, 2007, 7, 1, 22-37, ISSN 1583-4433.

10. Cavanagh, P.R., Lafortune, M.A., Ground reaction forces in distance running, J Biomech, 1979, 13, 397-406.

11. Novacheck, T.F., The biomechanics of running, Gait and Posture, 1998, 7, 77-95.

12. Marasovic, T., Cecic, M., Zanchi, V., Analysis and Interpretation of Grand Reaction Forces in Normal Gait, Laboratory for Biomechanics and Control System, Faculty of Electrical Engineering, Mechanical Engineering and Naval Architecture, University of Split, Croatia, 2010.

Article received/Data primirii articolului: 28.01.2014

Accepted/Acceptat la data: 25.02.2014 